\title{
The Position of Expert Witnesses in Medical Malpractice Cases in Indonesia
}

\author{
Muhammad Hatta \\ Universitas Malikussaleh Lhokseumawe, Aceh \\ e-mail:muhammad.hatta@unimal.ac.id
}

\begin{abstract}
Medical malpractice is one of the most difficult professional errors to prove. In solving medical malpractice cases, law enforcement is always assisted by doctors by connecting experts to reveal the truth with their expertise. The position of doctors as experts is very important and strategic. However, it is not easy for a doctor who wants to become a expert witness because the relationship of the suspect is a colleague. If the doctor want to be an expert witness then his testimony in court is not objective or impressed protect his colleagues. This study suggests that in the completion of medical malpractice cases in court can apply the system of proof by changing the proof to the doctor. In addition, this study also suggests to resolve medical malpractice cases that can be solved through the way of mediation before pursuing litigation settlement. In the aspect of Islamic law, the position of expert witness (rayu al-khäbir) is very important to explain or interpreta case that is vague and difficult to prove. However, an evidentiary system unable to prove the medical malpractice case then Islamic law can justify by using other methods that can bring benefitin general.
\end{abstract}

\section{प]}

Malpraktik medik adalah salah satu kesalahan professional yang sangat sulit dibuktikan. Dalam menyelesaikan kasus malpraktik medik, penegak hukum selalu dibantu oleh dokter sebagai saksi ahli untuk mengukapkan kebenaran sesuai dengan keahlian yang dimilikinya. Kedudukan dokter sebagai saksiahli sangat penting dan strategis. Namun, tidak mudah mendapatkan dokter yang mau menjadi saksi ahli terhadap tersangka karena saksi ahli dengan tersangka adalah teman sejawat. Apabila dokter mau menjadi saksi ahli maka kesaksiannya di pengadilan dinilai tidak objektif atau terkesan melindungi teman sejawatnya. Penelitian ini menyarankan supaya dalam penyelesaian kasus malpraktik medik di pengadilan dapat menerapkan sistem pembuktian terbalik dengan memindahkan beban pembuktian kepada dokter. Selain itu, penelitian ini juga menyarankan supaya penyelesaian kasus malpraktik medik dapat diselesaikan melalui jalur mediasi sebelum menempuh penyelesaian secara litigasi. Dalam aspek hukum islam, kedudukan saksi ahli (rayu al-khābir) sangat penting untuk menerangkan atau menafsirkan suatu perkara yang kabur dan sulit dibuktikan. Namun, apabila sistem pembuktian dengan menggunakan saksi ahli tidak mampu membuktikan perkara malpraktik medik maka hukum islam dapat membenarkan menggunakan metode lain yang dinilai dapat mendatangkan maslahat secara umum.

Keywords: position; expert witness; medical malpractice cases; Indonesia 


\section{Introduction}

Medical malpractice is one of the professional crimes involving doctors or other health workers. ${ }^{1}$ According to Dagi, medical malpractice is a mistake where the doctor does not do the checkup, no judgment, not careful or meticulous in carrying out the medical action and running his profession does not in accordance with the standard that has been determined. ${ }^{2}$ However, Moelyatno views his medical malpractice space more broadly, not only with medical negligence acts alone but also involves a deliberate medical act that causes the patient in injury, disability or death. ${ }^{3}$

In the law enforcement process, the errors which involve professional parties such as doctors are very difficult to prove. Law enforcement is very difficult to understand medical recordings or other data relating to patient surgery procedures or other medical treatment stages run by doctors to their patients. According to Putri Nemie, a medical malpractice case is difficult to prove because of technical and complexity so that the layman is difficult to understand the ins and outs of the medical profession. ${ }^{4}$ In the report of The Woolf Report, United Kingdom also mentioned that the medical malpractice

1The term malpractice derives from English, namely malpractice or mala praxis. Malpractice is divided into two syllables ie"mal"the meaning is bad action or a mistake and "practice"means action, deed or practice. Medical malpractice can be interpreted as a bad action (bad practice) by the doctor to his patient in contrary to the applicablelaw. In Dutch, medical malpractice is called "Kunstfout" which implies an act that should not be practiced by a health professional and the consequences arising from medical malpractice can harm a person's health. Soerjono Soekanto, "Etika KesehatanEtika Kedokteran Hukum Medik," Majalah Hukum Varia Peradilan 2, no. 18 (March 1987), 6.

2 T.E. Dagi, "Medical Negligence," The Journal of Medicine and Philosophy 1, no. 4 (1976), 234-5.

${ }^{3}$ According Moelyatno deliberate action is done consciously or under the knowledge of the offender in doing a deed. For example, doctors perform an act of abortion, euthanasia or a doctor deliberately does not help patients, resulting in the death of the patient. While negligence occurs due to lack of attention, lack of care and lack of caution in performing surgery, treatment or treatment of the patient so unnoticed causes circumstances that are prohibited by the law such as injuries, disabilities or eliminate the lives of patients. Negligence is essentially the same as deliberate, but the difference is only in quality alone and the degree of accidental errors is higher than the error caused by negligence. Therefore, there are some opinions that distinguish medical malpractice with medical negligence. Creighton concludes that malpractice is considered synonymous with professional negligence. This is supported by the opinion of Mason-McCall Smith which mentions that malpractice is a term which is increasingly widely used as a synonym for medical negligence. Moelyatno, Asas-Asas Hukum Pidana (Jakarta: Rineka Cipta, 2000), 199; Helen Creighton, Law Every Nurse Should Know (USA: W.B. Saunders Company, 1986), 167; J. K. Mason and R.A. McCall Smith, Forensic Medicine for Lawyers (London: Butterworths, 1986), 339.

4Puteri Nemie, Adopting a No Fault Compensation System for Medical Injuries in Malaysia. A Myth or Reality? Issues in Medical Law \& Ethics (Kuala Lumpur: Medical Law and Ethics Unit Law Centre, 2003). 
case is more difficult to prove than other cases. Due to the difficulty of proving medical malpractice cases, the completion of medical malpractice cases in the court takes a very long time and requires enormous expenses. ${ }^{5}$

To reduce the difficulty in proving doctor's fault, law enforcement authorities are justified to use expert witnesses to explain, interpret or justify that the actions of the physician in the care of the patient may be justified or blamed. In the case of medical malpractice, most of the expert witnesses are used in the medical profession. However, in the aspect of proof of expert witness required in accordance with the needs of the case being handled by the law enforcement. As long as there is no relationship with the parties litigation then everyone can be an expert witness in accordance with the expertise.

In the process of law enforcement both criminal and civil law aspects, doctors are often asked to be expert witnesses to assist the judiciary to prosecute doctors suspected of having medical malpractice. But many parties who judge that the testimony of a doctor as an expert witness is not objective, biased and tend to defend his colleagues. In fact, many doctors refuse to be expert witnesses to avoid conflicts of interest between them. This article will describe the existence of expert witnesses in solving cases of medical malpractice in Indonesia. Then, this article will also address some of the obstacles in law enforcement against medical malpractice cases in Indonesia. Finally, this article will provide some solutions or suggestions for improvement in the completion of medical malpractice cases in Indonesia.

This research uses a qualitative method by using normative juridical approach. ${ }^{6}$ The research uses the technique of substance analysis (content analysis). ${ }^{7}$ Content analysis technique is a systematic research by analyzing a legal document relating to the cases of medical malpractice. The purpose of legalistic or doctrinal research is to discover, explain, analyze, and systematically present the facts, principles, concepts, theories, laws and law

\footnotetext{
5Dato' James Foong, Medical Neg. Claim: Evidence, Procedure, Trial \& Assessment of Damages, Issues in Medical Law \& Ethics (IIUM: Medical Law \& Ethics Centre, 2003), 58.

6J. Van Maanen, "Reclaiming Qualitative Methods for Organizational Research: Preface," Administrative Science Quarterly 24 (1979), 520-6; G. D. McCracken, The Long Interview (London: SAGE Publications Inc, 1988), 16.
}

7Anwarul Yaqin, "Legal Research and Writing," Malayan Law Journal 1 (2007), 10. 
enforcement institutions with the result to find new science and ideas to be suggested become a change or renewal. Although this study does not specifically compare between Islamic law and Indonesian law in its discussion, there is a little bit compromise or compare (comparative law) to the position of expert witnesses in the Islamic law. ${ }^{8}$

\section{The position of Expert Witness in the Completion of Medical Malpractice Cases}

In the judicial process, the witness is one of the indispensable evidence. ${ }^{9}$ Every person who submits a fact and data before the court is a process of proof of a person's event or deed. According to Keane, the evidence brought to the court can be grouped into several kinds such as testimony, hearsay evidence, objects as evidence (real evidence), evidence by letter or document (documentary evidence) direct testimony and circumstantial evidence. ${ }^{10}$

In the juridical aspect, under Article 1 Paragraph (26) Law no. 8 year 1981 about the Criminal Procedure Code determines that the witness is a person which can provide information for the sake of investigation, prosecution and judgment on a criminal case that he hears by himself, he sees by himself and his own experience. ${ }^{11}$ In Article 1 Paragraph (27) of the Criminal Procedure Code (KUHAP) also states that the witness's statement is one of the evidence in

8Watson argues that the comparative law approach is a study of the relationship between a country's legal system or comparing legislation between different legal systems existing in the world. Peter De Cruz, Comparative Law in a Changingworld (London: Cavendish Publishing Ltd., 1999), 6.

${ }^{9}$ The evidence comes from Latin evidencs and evidere meaning to show clearly, to make clear plainly certain to ascertain, to prove. Hamid Ibrahim and Maimoonah Hamid, Law of Evidence (Kuala Lumpur: Central Law Book Corporation SdnBhd, 1993), 1.

${ }^{10}$ In the book Evidence-Practice and Procedure, Paul interprets that the testimony is a direct statement from the witnesses presented before the court and conveys the information as evidence of the truth he knows. The testimony of a witness directly experiences, senses, sees and knows a fact or event directly and the witness is the first to know the facts related to the case (first hand knowledge). Hearsay evidence means a hearing testimony from others. This means that the witness did not know directly what happened. According to Chissick, hearsay evidence is evidence that is not direct, is what a witness testifies in court about what he heard from a third party who is not a person called as a witness. Andrian Keane, The Modern Law of Evidence, 5th ed. (London: Butterworths, 2000), 9; Agustine Paul, "Evidence-Practice and Procedure," Malayan Law Journal Sdn Bhd 5 (2003), 540; Michael Chissick, Electronic Commerce: Law and Practice (London: Sweet and Maxwell Ltd., 1999), 23.

11Rika Susanti, "Peranan Dokter sebagai Saksi Ahli di Persidangan," Jurnal Kesehatan Andalas 2, no. 2 (2013), 101. 
a criminal case in the form of testimony from a witness concerning a criminal event that he heard by himself, he sees it himself and his own experience by mentioning the reason of his knowledge. 12

In order to achieve the truth material, in certain cases, it is not sufficient to be based solely on witness testimony but law enforcement authorities need expert witness testimony to explain a fact that is still vague based on the knowledge possesses. ${ }^{13}$ According to Michael, an expert witness is someone who can deduce based on his experience of the facts or data of an event, either found by himself or by others and able to express his opinion. ${ }^{14}$ Expert witnesses are qualified persons in terms of their knowledge and experience to give opinions on a particular issue to the court. ${ }^{15}$

Noraini Ibrahim argues that in giving expert's testimony before the court, an expert witness must have several qualifications, such as: a) The practical knowledge and experience of the material discussed in the case; b) The ability to communicate about findings or opinions to be conveyed is clear, concise, and understandable to the laypeople; c) Flexible in terms of thought and confidence to modify opinions as new evidence or opposing arguments; d) The ability to think from different sides in order to master any situation that could happen in court; e) Attitude and appearance in the judiciary. ${ }^{16}$

\footnotetext{
12The development of the definition of witness testimony is expanding after the Constitutional Court's decision No. 65 / PUU-VIII / 2010, the definition of witness's testimony as evidence is the testimony of a witness about a criminal case that he hears by himslef, he saw by himself, and he experiences by his own by mentioning the reason of his knowledge, including the information in the context of the investigation, prosecution, and judgment of a crime which he did not always hear by himself, he saw himself, and he experienced by his own. M. Yahya Harahap, Hukum Acara Perdata tentang Gugatan, Persidangan, Penyitaan, Pembuktian dan Putusan Pengadilan (Jakarta: Sinar Grafika, 2012), 287.

${ }^{13}$ Statsky said expert is (1) One who is knowledgeable, through experience or education, in a specialized field (an expert on accident reconstruction). Master, authority, professional, virtuoso, connoisseur, gourmet, critic, practitioner. (2). Skilled and knowledgeable (expert witness). Qualified, competent, proficient, able, trained, experienced, professional, "pro", polished, versed, accomplished, schooled, adroit, dexterous, capable, ace, adept, apt, efficient. William Statsky, West's Legal Thesaurus/Dictionary (St. Paul: West Publishing Co., 1985), 300.

${ }^{14}$ Michael Der Manuelian, "The Role of the Expert Witness in Music Copyright Infringement Cases," Fordham Law Review 57, no. 1 (1988): 127-47, https://doi.org/10.1525/sp.2007.54.1.23.

${ }^{15}$ British Medical Association, "British Medical Association Expert Witness Guidance," Journal of Patient Safety and Risk Management 13, no. 4 (July 1, 2007): 143-46, https://doi.org/10.1258/ 135626207781251112.

${ }^{16}$ Noraini Ibrahim, "Membina Keterangan: Pemeriksaan Utama Sebagai Titik Permulaan," Jurnal E-Bangi:Jurnal Elektronik Fakulti Sains dan Kemanusiaan 3, no. 1 (2008): 4.
} 
In the Indonesian judicial system, the position of the expert witness is in the second position after witness evidence of the testimony. The testimony of an expert witness has become a "powerful weapon" for law enforcement authorities to prove and entrap criminals. In fact, there are some things that are very difficult to prove, can be solved with the help of expert witnesses such as the murder case of Wayan Mirna Salihin done by Jessica Kumala Wongso or better known as the "Jessica coffee" case. ${ }^{17}$ Jessica's case is very difficult to prove because the evidence and tools of evidence required to ensnare the perpetrator are very limited, the material used to kill the victim is made of a certain chemical substance, and the offender has planned carefully before the act of killing is carried out.

The expert description is very important and it is often used to assign a suspect, release or punish the defendant. Witness opinion is often used as a reference to decide the legal status of a person. Once the importance of the position and role of expert witnesses in a trial so that in the cases that attract public attention then the presence of expert witnesses are very much anticipated. Tay Pek San believes that although in court a case has the authority to decide a person guilty or free from any lawsuit, sometimes all judge's judicial decisions are based on the testimony of expert witnesses. ${ }^{18}$

The obligation of the doctor as an expert witness has been stipulated in Article 133 Paragraph (1) of the Criminal Procedure Code (KUHAP) which determines that in the event of an investigator for the interest of the judiciary handles a victim either injury, poisoning or death allegedly due to an offense, he is authorized to file a request for a judicial medical expert or doctor or other experts. This expert information will be used as valid evidence in court and may be given orally in (Articles 184 and 186 KUHAP). If a doctor or health worker deliberately fails to fulfill his obligations when called as an expert witness in a case allegedly related to a crime, then in a criminal case will be punishable by imprisonment of a maximum of nine months and in other cases,

\footnotetext{
${ }^{17}$ See: “Keputusan Pengadilan Negeri Jakarta Pusat No. 777/2016/PN” (2016); “Putusan Banding Pengadilan Tinggi Jakarta Pusat No.393/PID/2016/PT.DKI" (2016).

18Tay Pek San, "Medical Negligence Litigation Call for a Reconsideration," Malayan Law Journal 3 (1998): lxxxi.
} 
threatened with a maximum of six months (Article 224 KUHAP). Article 170 of the Criminal Procedure Code states that the doctor for the work, the dignity of his or her position may use the right of retreat to be exempted from the obligation to give testimony as a witness, concerning the secret of medicine entrusted to him by giving the judge reason.

In other provisions, it is mentioned that the request for court assistance to the physician as an expert in accordance with legal procedures and as a good citizen, the doctor must fulfill the request from the court (Article 179 KUHAP)..$^{19}$ The doctor's request as an expert witness should be submitted by the court before the trial begins. Although there is a duty of a physician to provide testimony in court as an expert witness the physician may withdraw from an expert witness on the grounds justified by the judges' council. For example, the patient does not give permission to the doctor to open his medical record so that by reason of keeping the patient secret, the doctor may resign as an expert witness.

Theoretically, the expert witness is divided into two namely the witness of fact and the witness of opinion. For example, in the case of medical malpractice, a fact expert witness is a doctor who performs an operation or a doctor directly caring for the patient. The doctor will explain the facts, data, and information related to the medical action that has been done on his patient. An independent witness or called opinion witness is an independent expert witness who is asked to provide an independent opinion based on the facts of a particular case already in existence. In this case, the doctor will provide opinions in accordance with relevant experience and expertise. As an independent expert witness, doctors can assist the courts in two ways, namely by providing expert opinions based on their knowledge and experience of facts and informing the court of matters relating to their particular expertise so that before the doctor

\footnotetext{
${ }^{19}$ According to the Australian Medical Association, doctors have the obligation to help the courts and petrify other dispute resolution processes by giving testimony according to their expertise. Doctors must provide expert evidence to assist courts that are impartial, honest, objective and limit their opinions only within the scope of their expertise. However, the physician also has an obligation to protect the privacy and confidentiality of his patients from all the evidentiary processes he has done in court. Australian Medical Association, "Ethical Guidelines for Doctors Acting as Medical Witnesses 2011 (Revised 2016)," Australian Medical Association, 2017, https://ama.com.au/ position-statement/ethical-guidelines-doctors-acting-medical-witnesses-2011-revised-2016.
} 
gives expert testimony, the physician must know his position as a witness of fact or independent witness. ${ }^{20}$

The use of expert witness testimony is very high value because it will reveal a truth related to a specific crime and includes as a crime involving a professional group so to crack down on the perpetrator requires a sophisticated proof approach as well. However, Aminuddin argues that the testimony of expert witnesses is a supporting statement to the testimony of his witness. This supporting information may be in the form of oral, written, and in the other forms. The expert's description should be able to explain and justify the causal relationship between a person's actions and the consequences of the action so as to harm the others. ${ }^{21}$

In the judicial process, all parties, both the defendant's legal counsel and the Public Prosecutor, can present expert witnesses who are judged to be able to help explain the case in hand. Expert witnesses may be submitted more than one and if there is any doubt about the expert witnesses that have been filed then the litigants may present other expert witnesses to deny the expert's previous testimony so that the expert witness testimony is very persuasive and confident to the judge to establish a decision. ${ }^{22}$

In Islamic law, the position of a witness or expert witness is necessary. Witness or testimony is called al-shahädah which means a definite statement or gift, a speech that comes out of the knowledge obtained by direct witnessing, knowing something definitively, experiencing, and seeing it. According to shara', testimony is a definite notification of speech that comes out and obtained from the knowledge obtained by direct testimony. ${ }^{23}$ In the book of alTuruq al-Hukmiyah, Ibn Qayyim mentions that shahadah is to establish information to establish the rights of others. With sufficient testimony, the

\footnotetext{
${ }^{20}$ N H S S Tan, "Deconstructing Paternalism-What Serves the Patient Best?" Singapore Medical Journal 43, no. 3 (2002): 148-51.

${ }^{21}$ Aminuddin Mustafa and Siti Nurul Aziera Moharani, "Isu dan Permasalahan Keterangan Kanakkanak di Bawah Undang-Undang di Malaysia: Satu Penilaian," Journal Kanun 1, no. 1 (2012): 61.

${ }^{22}$ G. Stygall, Trial Language: Differential Discourse Processing and Discursive Formations (Amsterdam: John Benjamins Publishing Co., 1994), 132.

23Sulaikin Lubis, Hukum Acara Perdata Peradilan Agama di Indonesia (Jakarta: Kencana Prenada Media, 2006), 139.
} 
truth is true for the judge and he must decide the case according to the testimony. ${ }^{24}$ According to Wahbah al-Zuhayliy, testimony is a correct (statement) notice to prove a truth with the lafaz shahada's in front of the court.25

The testimony of an expert is one of the methods of verification conducted in the judicial process. According to the term, an expert witness is called ra yu al-Khabir or al-Khabir which means a testimony from someone who has expertise in a particular field. ${ }^{26}$ In the Dictionary of Modern Written Arabic, it is mentioned that the plural meanings of al-khibrä are those who have the expertise, strengths, experience, skills, knowledge, recognize and study a particular case and have value and privilege in a particular field. ${ }^{27}$

In the Qur'an, Allah said in Surah al-Nahl, verse 43:

"And We have not sent before you, except the men whom We have revelated unto them; then ask the knowledgeable if you do not know".

In the next sura, Allah said in Surah al-Anbiyā', verse 7:

"We have not sent messengers before you (Muhammad), but some men whom We have revealed to them, then ask for those who have the knowledge, if you do not know".

Both surah and verses above mention that "zikr experts" interpreted by mufassirin like Ibn Abbas as someone who is expert in the field of al-Qur'an, the expert of Science or other meaning that the corresponding expert opinion is categorized as "zikr experts" and "knowledge expert". ${ }^{28}$ Someone which called by "zikr experts" and "knowledge experts" is the people who are professionals, possess skills, expertise in a particular field. If a judge has difficulty in making a decision on a particular case then let a judge ask the parties who know the case. $^{29}$ Every expert witness must have the obligation to provide the

\footnotetext{
24Ibn al-Qayyim al-Jauziyah, al-Ṭuruq al-Hukmiyah (Beirut: Dār al-Ma'rifah, 1408 H/1988 M), 114.

25Wahbah al-Zuhayliy, Fiqh Al-Islām Wa Adillatuhu (Beirut: Dār al-Fikr, 1409 H/1989 M), 328.

26al-Jauziyah, al-Ṭuruq al-Hukmiyah, 188.

${ }^{27}$ Hans Wehr, A Dictionary of Modern Written Arabic (London: MacDonald \& Evans Ltd., 1980), 243.

${ }^{28} \mathrm{Abī}$ 'Abdullāh Muḥammad bin Aḥmad al-Anșāriy al-Qurțubiy, al-Jāmi' li Aḥkām al-Qur'ān (Qāhirah: Dār al-Sha'bi, n.d.),3724.

${ }^{29}$ Aḥmad Fatḥi Bahansi, Naẓariah al-Ithbāt (Mesir: al-Sharikah al-'Arabiyyah li al-Ṭibaah, 1962), 344.
} 
information required by the court. The expert witness must give his or her testimony freely, honestly, objectively and restrict his or her opinion only with regard to his or her expertise. A person is considered as an expert if they have special skills that can help the court to settle a case fairly. ${ }^{30}$ The information conveyed by expert witnesses is considered important because it relates to science and technology that are independent based on knowledge. However, not all statements from expert witnesses are accepted by the court, if the judge gets any doubt, so the judge may call the other expert witnesses to clarify the case being tried in court. ${ }^{31}$

\section{The Expert Witness and The Problems}

In the civil aspect, the party who has the duty to prove the doctor's error is the patient and his legal counsel. The patient should be able to prove that the doctor has been negligent in performing surgery or other medical actions so that the patient is injured, disabled or not recovered from his illness. According to Giesen, the patient must prove a direct connection between the cause and the effect of the doctor's actions on behalf of the patient. ${ }^{32}$ However, it is not easy for the patient to prove a doctor's error because the patient has no knowledge of medical science and the patient does not know the doctor's actions at the time of surgery because the patient is unconscious.

To assist patients in winning their cases, the legal instruments provide the right or opportunity to the patient to obtain expert witnesses who understand the theoretical and clinical knowledge of medicine. Parties who know the science of medicine, care, surgery, and recovery is the medical profession itself. However, it is not an easy matter for a patient to get a doctor who will be an expert witness and willing to testify in court that his colleagues have malpractice medical treatment on his patients. Any dilemma for the doctor's to be an expert witness in court. On the one hand, doctors have an obligation to

\footnotetext{
30Paul, "Evidence-Practice and Procedure," 124.

${ }^{31}$ G. Stygall, "A Different Class of Witnesses: Experts in the Courtroom," Discourse Studies 3, no. 3 (August 1, 2001): 327-49, https://doi.org/10.1177/1461445601003003004.

32 “... establishing a causal connection between medical negligence and the damage alleged is often the most difficult task for a plaintiff in medical malpractice litigation..." D. Giesen, International Medical Malpractice Law (London: Sweet and Maxwell Ltd., 1988), 268.
} 
assist law enforcement in cracking down on doctors who perform medical malpractice. However, on the other hand, the doctor will deal with his colleagues and his statements can imprison, revoke the practice license and even kill his colleague's career. It is difficult for a doctor to be an expert witness to maintain his integrity and his independence in giving testimony in court.

Another obstacle is that the doctor is one of the profound adherence professions to the oath and the code of ethics of his profession. Understanding and adherence to the oath and code of ethics of the medical profession have been implanted since the education both medical study and medical specialist. One of the ethics instruments in the medical profession is that a doctor must safeguard, protect and treat his colleagues well in his profession. ${ }^{33}$

This ethical principle derives from the oath of Hippocrates (Hippocratic Oath) in order to maintain a good relationship between doctor and doctor, the doctors and teachers, the doctors and society. ${ }^{34}$ Hippocratic Oath aims to manifest attitudes and respect, fraternity, and help in the running of the medical profession. However, these ethical principles are often misunderstood in the running of the medical profession and it is applied to daily life. The meaning contained in the hypocrisy vow is to keep the friend's relationship in the best of good things to improve the quality of health service to the public rather than to defend the colleague who does mistakes so that he justifies all wrong actions carried out by his colleagues. ${ }^{35}$

Doctors who are asked to the proceedings to explain the facts that are unclear or discontinuous that cause the judge doubt in making the decision. Ideally, the doctor as an expert witness should prioritize the court's interest to find the truth rather than to defend his colleague. Information from expert

\footnotetext{
33In the doctoral oath of Indonesia stated "saya akan perlakukan teman sejawat saya sebagaimana saya sendiri ingin diperlakukan".In the Article 15 of the Indonesian Medical Code of Ethics mentioned that"setiap doktermemperlakukan teman sejawatnya sebagaimana ia sendiri ingin diperlakukan".

34"To regard my teacher in this art as equal to my parents; to make him partner in my livelihood, and when he is in need of money to share mine with him; to consider his offspring equal to my brothers..." W.H.S. Jones, The Doctor's Oath (English Translation) (Cambridge: Cambridge University Press, 1924), 11-12.

35 Muhammad Hatta et al., "Role of the Doctor as Expert Witness in Medical Malpractice Cases," in The 1th Al-Muslim International Conference on Science, Technology and Society (AICSTS) (Indonesia, November 7-8, 20152015), 373.
} 
witnesses should explain a fact and not vice versa the facts. If expert witnesses provide incorrect information during court proceedings, the judge's decision may harm the patient. According to Pan Say, in the case of medical malpractice, although many other pieces of evidence are brought to trial, the judges always base their decisions on the expert witnesses. ${ }^{36}$

It is rare to find that expert witnesses who testify in court are different and contrary to the medical practices that run by the suspect. Mostly, expert witnesses justify the actions of their colleagues, because in surgical techniques or other medical actions only the doctor knows. Brazier argues that judges in British courts have also ruled that medical malpractice cases are always based on expert witness statements. The problem is very rarely found that the testimony of a doctor who is an expert witness is different from or contrary to the actions taken by the doctor accused of medical malpractice. There are so many judges in the British courts that only accepts the testimony of expert witnesses without trying to analyze or challenge the opinion of the expert witness. ${ }^{37}$

The next obstacle is that doctors do not want to be an expert witness with the reason that the doctors are obliged to respect and keep the patient secret. The prohibition on disclosing the patient's secrets is set out in the Geneva Convention of $1948 .{ }^{38}$ However, before the Geneva convention, Judge Lord Ridell mentioned that the doctor was obliged to keep and keep his patients secret. ${ }^{39}$ Article 16 specifies that every doctor is obliged to keep any secret that he or she knows about a patient, even after the patient dies. The same is regulated in Article 73 (1) of Law no. 36 of 2004 on Health Manpower that Every Health Worker in performing health service must keep health secrets of Health Service Recipient. The duty of patient confidentiality is reaffirmed in Article 57 (1) of Law no. 36 The year 2009 on Health determines that every

\footnotetext{
36Ninik Mariyanti, Malapraktek Kedokteran dari Segi Hukum Pidana dan Perdata (Jakarta: Bina Aksara, 1988), 37.

${ }^{37}$ Brazier said, "The judges in England defer in most part to the views of the doctors. Unlike their American brethren, English judges will rarely challenge the accepted views of the medical profession. Margaret Brazier, Medicine, Patients and the Law (London: Penguin Books, 1992), 21.

38Mohammed Imran et al., "Hippocratic Oath and Conversion of Ethico-Regulatory Aspects onto Doctors as a Physician, Private Individual and a Clinical Investigator," Journal of Mid-Life Health 4, no. 4 (2013): 203-9, https://doi.org/10.4103/0976-7800.122232.

39 M. Kartigesu, "Medical and Privilege," Malayan Law Journal 1 (1979): xi.
} 
person is entitled to the secrecy of his/ her personal health condition which has been addressed to the health service providers.

The doctor must understand that the obligation of a patient's confidentiality is not absolute. The obligation can be set aside for several reasons, such as a) Orders of the law; b) Court order; c) The permit concerned; d) Community interest; e) The person's interests. ${ }^{40}$

The next problem is the doctors present at the trial as expert witnesses always provide information that defends the people who present it. For example, a doctor who becomes an expert witness presented by the legal advisor then the expert witnesses tend to defend the interests of his client. On the contrary, if the expert witness is presented by the Prosecutor then the testimony of the expert witness will defend the Public Prosecutor's interest. According to Munir, the expert witness who gave testimony in the court tended to be partial to the party who presented him in the trial. Even before a person is asked to be an expert witness in the case of a suspect, the legal advisor or public prosecutor makes sure to the expert witness in order to provide information that defends his interests. ${ }^{41}$

\section{Solutions and Analysis}

In the theory of proof says that "he who asserts must be proved" or in Dutch is called (wie stelt, moet zijn recht kunnen bewijzan). In the aspect of civil law, the party that is obliged to prove the doctor's mistake is the patient and in the aspect of the criminal law which has the duty to prove the doctor's error is the public prosecutor. According to Lord Denning L.J., if the patient or a litigant who proves a doctor's negligence so he can not possibly do so. ${ }^{42}$

The difficulty of proving the doctor's errors has been mentioned in the US Department of Health, Education and Welfare report. ${ }^{43}$ According to Puteri

40See Article 73 Paragraph (3) of Law Number 36 Year 2004 regarding to Health Manpower and Article 57 (2) of Law no. 36 Year 2009 about Health. 627.

41M. Monir, Principle and Digest of the Law of Evidence (Pakistan: University Book Agency, 1977),

42J. Guwandhi, Hospital Law (Emerging Doctrines \& Jurisprudence) (Depok: Badan Penerbit Fakultas Kedokteran Universitas Indonesia, 2013), 68-9.

${ }^{43}$ Dieter Giesen, International Medical Malpractice Law: A Comparative Study of Civil Responsibility Arising from Medical Care (Netherlands: Springer Netherlands, 1988), 521. 
Nemie, the difficulty of proving the medical malpractice case has become an inhibiting factor for patients or families of patients to file a lawsuit against a doctor to court because the patient does not have the ability to prove the elements contained in medical malpractice. ${ }^{44}$ If the evidentiary system is still maintained then it will realize injustice to the patient ${ }^{45}$ That's why it is necessary to change the evidentiary system against medical malpractice cases.

Globally, the proof principle of he who asserts must prove has been abandoned, especially in certain cases. This principle of proof lays the burden of proof is considered irrelevant to the development of the times and cause problems of justice to the patient as a victim. Doctors are considered more relevant and rational if the burden of proof is done by the doctor. As a professional group, doctors are considered to know more and understand medical science and technical operations or other medical actions. Reversed proof of medical malpractice cases has begun to be applied in various countries such as Switzerland, the Netherlands, ${ }^{46}$ Belgium, ${ }^{47}$ Italy, and Ireland, ${ }^{48}$ All these countries recognize that it would be unfair if the state imposes an evidentiary obligation to the patients who have no medical education background as the doctor himself.49

Lord Justice May mentioned that moving the burden of proof from the patient to the doctor will bring a positive change in the law enforcement

\footnotetext{
44Puteri Nemie Jahn Kassim and Khadijah Mohd Najid, "Medical Negligence Disputes in Malaysia: Resolving through Hazards of Litigation or through Community Responsibilities?" World Academy of Science, Engineering and Technology International Journal of Humanities and Social Sciences 7, no. 6 (July 2013): 1758-65, http://wasetorg/publications/3517.

45 If the present system is to be retained, some changes have clearly to be made. One of the major criticisms of the tort system concerns the difficulties facing patients and their relatives in bringing a claim against doctors. The tort system is criticized because the plaintiff bears the burden of proving all components of the medicalnegligence claim. Kassim and Naijd, "Medical Negligence Disputes in Malaysia."

${ }^{46} \mathrm{Cf}$. W. Asser, "Stelplicht en Bewijslastverdeling en Medische Aanspra-Kelijk Heid in Het Nederlandse Recht," Tijdschrift Voor Gezondheidsrecht 27 (1991), 228.

${ }^{47}$ Court of Appeal of Liege, $30^{\text {th }}$ April 1998, Court of Appeal Antwerp, $22^{\text {th }}$ July 1998, Tijdschrift Voor Gezonddheidsrecht/Revue de Droit de La Sante, Belgia, 1998-1999, 144.

${ }^{48}$ Nihal Jayawickrama, Jeremy Pope, and Oliver Stolpe, "Legal Provisions to Facilitate the Gathering of Evidence in Corruption Cases: Easing the Burden of Proof," Forum on Crime and Society 2, no. 1 (December 2002): 24-25.

49The Cour de Cassation, Frace, 27 April 1997 in Guwandhi, Hospital Law (Emerging Doctrines \& Jurisprudence), 53.
} 
process against medical malpractice cases because the doctor is more knowledgeable, understanding, experienced and have competency about medical science. ${ }^{50}$ Ramalingam said that the burden of proof will facilitate the verification process because the doctors have access to evidence and expert witnesses.

"In principle, both litigants, plaintiff, and defendant have the same responsibility to prove their case in court. However, if the defendant has the competence and expertise of the facts in the case, the burden of proof could be transferred to the defendant to facilitate the process of proving in court. In addition, it is the case that the plaintiff to prove the defendant is guilty because all of the evidence needed is confidential. Had the liability of proving the case be transferred to the defendant, then proving will be easier." 51

In Islam, the principle of reversed proof has existed since the time of prophethood. It can be seen in the story of the Prophet Yusuf who was prosecuted because of indecent acts against Zulaikha. Allah said in the Surah Yūsuf, verses 26-29:

"Yūsuf said "he teased me to subdue myself (to him), "and a witness from the woman's family gave her testimony," if his shirt is torn in the face, then she is right and Yūsuf belongs to those who lie. If the shirt is torn behind, then that woman is a lie, and Yūsuf is among the righteous. "So when the woman's husband sees Yūsuf's shirt torn behind, he said" it is between your deceit (my wife). Surely your deceit is great. "(Hi) Yūsuf" turn away from this, and (you, my wife) ask forgiveness for your sins, for you are indeed among those who do wrong."

The Word of Allah stated that the trial court between Zulaikha as the accuser and the prophet Yūsuf as the accused. Zulaikha accused Yusuf in the presence of the Egyptian ruler (as her husband) that Yūsuf had seduced her to commit an act of adultery against her. Yūsuf rejected the accusation and explained that what happened was the opposite of what was alleged to him. The Egyptian ruler was puzzled by the question, and one of the court's families proposed that evidence is seen to explain the true nature of the event by observing the condition of the clothing worn by Yūsuf. If Yūsuf's clothes were

\footnotetext{
50Dwyer v. Roderick [1983] 127 SJ 805 (CA).

51Ramalinggam, "Reversal Burden of Proof in Malaysia” (2016), Interview, Lecturer at Faculty of Law, Universiti Kebangsaan Malaysia, 17 Mac 2016; PS. Rajan, Medical Negligence Litigation: Time for Reform, Issues in Medical Law and Ethics (Kuala Lumpur: Medical law and Ethics Unit, Law Centre, 2003), 71.
} 
torn in the front, then Yūsuf was the one who had the initiative to do the perversion. But if the tear is behind, then Zulaikha is wrong. Yūsuf then shows his torn shirt in the back as proof that he will avoid Zulaikha's seduction, but it is pulled by Zulaikha from behind. The Egyptian ruler accepted the proof of Yūsuf and rejected Zulaikha's accusations, then he decided that Zulaikha was wrong.

The explanation of the Qur'an shows that when a matter is very difficult to decide because there is no evidence or witness that the accuser can bring in the proceedings to substantiate his allegations, the judge may ask the accused to present evidence of the thing being held. However, the application of reversed proofs only to cases that are difficult to prove because of the limitations of the valid evidence, may be justified by Islam because of the way it is perceived to bring about the benefit in general. If this method becomes the only alternative that can guarantee the realization of common benefit, then not only can be done, but it must be. 52

Besides implementing reverse evidentiary burden systems as a solution to solve medical malpractice cases through courts, some countries around the world have used non-litigation resolution mechanisms or alternative dispute resolution by using a mediation approach. ${ }^{53}$ Freedman \& Prigoff mentioned that mediation is the simplest and most economical dispute resolution mechanism because the mediation mechanism does not have a formal proofing procedure so it can be done quickly and does not cost much. ${ }^{54}$ Usually, the most needed time in court is the evidentiary process because the conflicting parties carry documents and present witnesses to strengthen their demands or defend their arguments. The longer the verification process in court then the more costs will be needed.

Laurence Bolle mentions that:

\footnotetext{
52 Budi Kisworo, "Urgensi Penerapan Asas Pembuktian Terbalik Menurut Hukum Acara Islam," Miqot: Jurnal Ilmu-ilmu Keislaman 36, no. 1 (2012): 106-7, http://jurnalmiqotojs.uinsu.acid/ index.php/jurnalmiqot/article/view/110/100.

${ }^{53}$ Aida Othman, "Introducing Alternative Dispute Resolution in Malaysia: Prospects and Challenges," Malayan Law Journal 2 (2002): 224.

${ }^{54}$ Lawrence R. Freedman and Michael L. Prigoff, "Confidentiality in Mediation: The Need for Protection," Ohio State Journal on Dispute Resolution 2, no. 1 (1986):37-46.
} 
"Mediation is a decision-making process in which the parties are assisted by a mediator."55

J. Folberg and A. Taylor also explained that:

“... The process by which the participants, together with the assistance of a neutral person, systematically isolate dispute in order to develop options, consider the alternative, and reach a consensual settlement that will accommodate their needs." 56

The case settlement through mediation is led by a mediator who is independent or has no relationship with the litigants. The American Bar Association (ABA) stated that mediators are not bound by standard procedures such as court settlement. The mediator is free to determine what mechanism that he considers appropriate to the case he is handling. One of the most important things is that the mediator must be able to create a comfortable mediation forum so that the parties to the dispute can think quietly and can produce acceptable decisions and satisfy all parties. The mediator must know and understand all stages of mediation if the mediator finds either party imposing coercion, dishonesty, fraud or an unbalanced position, the mediator is entitled to stop the mediation process. ${ }^{57}$

In the aspect of settlement of medical malpractice case, article 29 Law no. 36 The year 2009 on Health has decided that In the case of health personnel suspected of negligence in carrying out his profession, the omission must be solved first through mediation. Under this provision, mediation is made in the case of a dispute between health staff as providers of health services with the patients as recipients of health services. The litigants are not encouraged to take their case to lawyers or courts because the court process will take a longer time, high cost and create an atmosphere of hostility between doctors and patients. However, the patient still needs the energy or health service of the doctor or another physician to heal himself. Therefore, hatred and hostility between doctors and patients will harm the patient itself.

55Laurence Bolle, Mediation: Principles, Process, and Practice, in Syahrizal Abbas, Mediasi Dalam Perspektif Hukum Syariah, Hukum Adat, \& Hukum Nasional (Jakarta: Kencana Prenada Media, 2009), 4.

56J. Folberg and A. Taylor, Mediation: A Comprehensive Guide to Resolving Conflict without Litigation, in Abbas, Mediasi dalam Perspektif, 4.

${ }^{57}$ American Bar Association (ABA), ABA Model Rules of Professional Conduct (Chicago: American Bar Association (ABA), 2011), Rule 2.2. 
Completing the case through mediation will keep doctors and patients away from each other. In the mediation process, we do not talk about who is wrong and who is right. The mediator only leads, what solutions are needed and provides benefits to both parties. Disputingresolution through mediation using win-win solution or win-win situation.58 This approach positioned the parties in the mediation negotiation forum to feel won or no one is harmed. All things that still incriminate the hearts of dissatisfaction can be discussed and look for solutions to lighten the burden on both sides to avoid suspicion, hatred and hostility between the parties who play a role.

The concept of mediation is not only found in western law but the concept of mediation is also contained in the Khazanah of Islamic science. The term mediation in Islam is called al-șulh which means qat al-nizä' ie settling quarrels, and disputes. Ibn Manzur stated that șulh is a name of al-mașlahah which means peaceful, but the antonym of the term al-mașlahah is al-muhasanah it is a conflict or hostility..$^{9}$ According to shara', al-sulh is a contract that produces an agreement to end a dispute. ${ }^{60}$ Since the time of the Prophet Muhammad (peace and blessings be upon him), al-șulh was done in various forms such as reconciling between husband and wife who was fighting, reconciling the conflict between the Muslims and the groups of infidels. Al-sulh became a method of reconciling disagreements between the two parties on the basis of sincerity or willingness of each disputing party to override the judicial process.

Al-șulh in Islamic law aims to reconcile the parties to the dispute. Although al-sulh is permissible among Muslims, the settlement of disputes through alsulh is restricted to those whose subject and object are lawful. If it makes something halāl to be haräm or vice versa then al-șulh cannot be executed. This is explained in the hadith which narrated by Ibn Hibban and Tirmidhi from 'Umar ibn Auf al-Muzanni, Rasulullah said:

"Had told us [al-Hasan bin Ali al-Khallal], had told us [Abu Amir al-'Aqad], had told us [Kathīr bin 'Abdullāh bin Amru bin 'Auf al-Muzani] from [his father] from [his grandfather] that the Messenger of Allaah (peace and blessings of Allah be upon him) said: "Peace is permissible among the Muslims except for

58Khee Quan Yeo, et al, Essentials of Medical Law (Singapore: Sweet \& Maxwell Asia, 2004), 355.

59Ibn Manzūur, Lisān al-'Arab, jilid 2 (Beirut: Dār al-Fikr, 1386 H), 516-17.

${ }^{60}$ Sayyid Sābiq, Fiqh al-Sunnah (Beirut: Dār al-Fikr, 1977); Mușțaā al-Khīn, al-Fiqh al-Manhajïy (Damascus: Dār al-Qalam, 1998), 149. 
peace which forbids the lawful or permissible the unlawful, and the Muslims may determine the condition except the conditions forbidding the lawful or lawful of the haram". (HR. Tirmidhi). ${ }^{61}$

In the concept of al-sulh, the position of a mediator is also recognized. Saleh Buang mentioned that al-sulh is a guided discussion process which is done in accordance with shara' law. The settlement of disputes through al-șulh is done openly, voluntarily, not emotionally and grudgingly. ${ }^{62}$ The spirit in settlement through al-sulh is the parties which have the desire to settle their dispute without harming the other and giving the equality to all parties. Therefore, dispute settlement through al-șulh can be done quickly so that it can save cost, time and effort.

The concept of al-sulh and mediation is almost the same, but what distinguishes the concept of al-șulh is the criteria and conditions that must be obeyed. One of the conditions that must be obeyed in the settlement through al-sulh is the subject and the object must be lawful (haläl) or not contrary to other shara' law. However, the mechanism of al-șulh that is technical is still based on the agreement of both parties. For example, the parties to the dispute have the freedom to decide mediators in mediating or leading a forum of negotiation through al-șulh

\section{Conclusion}

The presence of expert witnesses in the courts is aimed at clarifying and explaining some facts that are vague, lost and disconnected. The role of expert witnesses is very strategic to prove the negligence done by the doctor in carrying out his profession. Even in the verification process, the judge desperately needs expert witness testimony because only an expert witness is able to explain the method of treatment, surgery, patient diagnostic analysis or medical record of the patient. Such importance the position of the expert witness in medical malpractice cases so that judges who have authority to decide whether the doctors do a medical malpractice or not, but the judge's decision is always based on the information given by expert witnesses in court.

\footnotetext{
61Ahmad Ibn 'Ali Ibn Hajar al-'Asqalaniy, Bulūgh al-Marām (Beirut: Dār al-Fikr, n.d.), 184.

62Salleh Buang, "Mediasi Mahkamah Syariah," Kertas Kerja Kursus (Hotel Quality Shah Alam, Selangor DarulEhsan, 22-24 April 2002), 2.
} 
In the aspect of Indonesian law, the doctor's position as an expert witness is very strong to assist the judges in the trial of medical malpractice cases. The Criminal Procedure Code and the Civil Procedure Code have confirmed that the doctor has the obligation to be a witness either a regular witness or an expert witness to fulfill a court summons to give testimony relating to his or her expertise. However, there are some obstacles in presenting expert witnesses in court. For example, doctors do not want to be expert witnesses with the reason the doctors do not receive permission to disclose patients' secret, the doctors do not obtain the complete case files, doctors do not prepare testimony in court and there are many other reasons.

Facts found in this study, although doctors are willing to be an expert witness in front of the court then the doctor tends to defend his colleagues. It is rare to find a physician who is an expert witness in court to testify differently or against a medical practice run by a suspect. Mostly, expert witnesses justify the actions of their colleagues, because in surgical techniques or other medical actions only the doctor knows.

Other obstacles, the litigants are difficult to find a doctor who has the expertise required by the court. Typically, parties are encouraged to seek out specialists outside the region and this is particularly burdening to the litigants. The difficulty of bringing expert witnesses causes the parties to litigation to seek witnesses who want and must defend their interests. For example, a doctor who becomes an expert witness presented by the legal advisor then the expert witnesses tend to defend the interests of his client. On the contrary, if the expert witness is presented by the Prosecutor then his testimony will defend the Public Prosecutor's interest.

This study provides a solution that the settlement of medical malpractice cases through the court can apply the reverse verification system by putting the burden of proof to the doctor himself. Globally, reversed evidence against medical malpractice cases has been applied. In the aspect of Islamic law, the principle or concept of inverse proof has long existed and applied to various cases both civil cases and criminal cases. Therefore, the reversed proof principle against medical malpractice cases can also be applied in Indonesia by making changes to laws relating to the enforcement of health laws.

The study also suggests that the patient or the patient's family should not immediately bring the alleged medical malpractice to the legal ground but it is 
better the case is resolved in a familial way through the mediation mechanism. Mediation is carried out by an independent and neutral mediator so that the interests of the disputing parties can be accommodated. Mediation itself has been used in Law no. 36 The year 2009 on Health but unfortunately medical malpractice cases more settled through court than mediation settlement.

The concept of mediation is also found in Islamic law. Islam strongly prioritizes the settlement of disputes through discussion and peace. In the concept of Islamic law, the concept of mediation is called al-șulh or al-mașlahah which means peace. The concept of al-sulh is similar to mediation, but what distinguishes the concept of al-sulh with the mediation, al-sulh has the criteria and conditions which specified in al-Qur'an and al-Hadith that must be obeyed by the disputing parties and mediators as parties pensioner in a related case.[a]

\section{BIBLIOGRAPHY}

Abbas, Syahrizal. Mediasi dalam Perspektif Hukum Syariah, Hukum Adat \& Hukum Nasional. Jakarta: Kencana Prenada Media, 2009.

American Bar Association (ABA). ABA Model Rules of Professional Conduct. Chicago: American Bar Association (ABA), 2011.

al-'Asqalaniy, Aḥmad Ibn 'Ali ibn Ḥajar. Bulūgh al-Marām. Beirut: Dār al-Fikr, n.d.

Asser, Cf. W. "Stelplicht En Bewijslastverdeling En Medische Aanspra-Kelijk Heid in Het Nederlandse Recht." Tijdschrift Voor Gezondheidsrecht 27 (1991).

Australian Medical Association. "Ethical Guidelines for Doctors Acting as Medical Witnesses 2011 (Revised 2016)." Australian Medical Association, 2017. https://ama.com.au/position-statement/ethicalguidelines-doctors-acting-medical-witnesses-2011-revised-2016.

Bahansi, Ahmad Fathi. Naẓariah al-Ithbāt. Mesir: al-Sharikah al-Arabiyyah li alTiba'ah, 1962.

Brazier, Margaret. Medicine, Patients and the Law. London: Penguin Books, 1992. 
British Medical Association. "British Medical Association Expert Witness Guidance." Journal of Patient Safety and Risk Management 13, no. 4 (July 1, 2007): 143-46. https://doi.org/10.1258/135626207781251112.

Buang, Salleh. "Mediasi Mahkamah Syariah.” Kertas Kerja Kursus. Hotel Quality Shah Alam, Selangor Darul Ehsan, 2002.

Budi Kisworo. "Urgensi Penerapan Asas Pembuktian Terbalik Menurut Hukum Acara Islam." MIQOT: Jurnal Ilmu-ilmu Keislaman 36, no. 1 (2012): 10321. http://jurnalmiqotojs.uinsu.ac.id/index.php/jurnalmiqot/article/ view/110/100.

Chissick, Michael. Electronic Commerce: Law and Practice. London: Sweet and Maxwell Ltd., 1999.

Creighton, Helen. Law Every Nurse Should Know. USA: W.B. Saunders Company, 1986.

Cruz, Peter De. Comparative Law in a Changing World. London: Cavendish Publishing Ltd., 1999.

Dagi, T.E. "Medical Negligence.” The Journal of Medicine and Philosophy 1, no. 4 (1976).

Dwyer v. Roderick [1983] 127 SJ 805 (CA) (n.d.).

Foong, Dato' James. Medical Neg. Claim: Evidence, Procedure, Trial \& Assessment of Damages, Issues in Medical Law \& Ethics. IIUM: Medical Law \& Ethics Centre, 2003.

Freedman, Lawrence R., and Michael L. Prigoff. "Confidentiality in Mediation: The Need for Protection." Ohio State Journal on Dispute Resolution 2, no. 1 (1986): 37-46.

Giesen, D. International Medical Malpractice Law. London: Sweet and Maxwell Ltd., 1988.

Giesen, Dieter. International Medical Malpractice Law: A Comparative Study of Civil Responsibility Arising from Medical Care. Netherlands: Springer Netherlands, 1988.

Guwandhi, J. Hospital Law (Emerging Doctrines \& Jurisprudence). Depok: Badan Penerbit Fakultas Kedokteran Universitas Indonesia, 2013.

Harahap, M. Yahya. Hukum Acara Perdata tentang Gugatan, Persidangan, Penyitaan, Pembuktian dan Putusan Pengadilan. Jakarta: Sinar Grafika, 2012.

Hatta, Muhammad, Tengku Noor Azira, Tengku Zainuddin, and Cut Khairunnisa. "Role of the Doctor as Expert Witness in Medical 
Malpractice Cases." in The 1st Al-Muslim International Conference on Science, Technology, and Society (AICSTS). Indonesia, 2015.

Ibrahim, Hamid, and Maimoonah Hamid. Law of Evidence. Kuala Lumpur: Central Law Book Corporation Sdn Bhd, 1993.

Ibrahim, Noraini. "Membina Keterangan: Pemeriksaan Utama Sebagai Titik Permulaan." Jurnal E-Bangi: Jurnal Elektronik Fakulti Sains dan Kemanusiaan 3, no. 1 (2008).

Imran, Mohammed, Shadab Samad, Mohammad Maaz, Ashhar Qadeer, Abul Kalam Najmi, and Mohammed Aqil. "Hippocratic Oath and Conversion of Ethics-Regulatory Aspects onto Doctors as a Physician, Private Individual, and a Clinical Investigator." Journal of Mid-Life Health 4, no. 4 (2013): 203-9. https://doi.org/10.4103/0976-7800.122232.

al-Jauziyah, Ibn al-Qayyim. Al-Ṭuruq al-Hukmiyah. Beirut: Dār al-Ma'rifah, 1988. Jayawickrama, Nihal, Jeremy Pope, and Oliver Stolpe. "Legal Provisions to Facilitate the Gathering of Evidence in Corruption Cases: Easing the Burden of Proof." Forum on Crime and Society 2, no. 1 (2002): 23-31.

Jones, W.H.S. The Doctor's Oath (English Translation). Cambridge: Cambridge University Press, 1924.

al-Khīn, Mușțafā. al-Fiqh al-Manhajìy. Damascus: Dār al-Qalam, 1998.

Kartigesu, M. “Medical and Privilege." Malayan Law Journal 1 (1979).

Kassim, Puteri Nemie Jahn, and Khadijah Mohd Najid. "Medical Negligence Disputes in Malaysia: Resolving through Hazards of Litigation or through Community Responsibilities?" World Academy of Science, Engineering and Technology International Journal of Humanities and Social Sciences 7, no. 6 (July 2013): 1758-65. http://waset.org/ publications/3517.

Keane, Andrian. The Modern Law of Evidence. 5th ed. London: Butterworths, 2000.

Keputusan Pengadilan Negeri Jakarta Pusat No. 777/2016/PN (2016).

Lubis, Sulaikin. Hukum Acara Perdata Peradilan Agama di Indonesia. Jakarta: Kencana Prenada Media, 2006.

Maanen, J. Van. "Reclaiming Qualitative Methods for Organizational Research: Preface." Administrative Science Quarterly 24 (1979).

Manuelian, Michael Der. "The Role of the Expert Witness in Music Copyright Infringement Cases." Fordham Law Review 57, no. 1 (1988): 127-47. https://doi.org/10.1525/sp.2007.54.1.23. 
Manẓūr, Ibn. Lisān al-'Arab. Beirut: Dār al-Fikr, 1386.

Mariyanti, Ninik. Malapraktek Kedokteran dari Segi Hukum Pidana dan Perdata. Jakarta: Bina Aksara, 1988.

Mason, J. K., and R.A. McCall Smith. Forensic Medicine for Lawyers. London: Butterworths, 1986.

McCracken, G. D. The Long Interview. London: SAGE Publications Inc, 1988.

Moelyatno. Asas-asas Hukum Pidana. Jakarta: Rineka Cipta, 2000.

Monir, M. Principle, and Digest of the Law of Evidence. Pakistan: University Book Agency, 1977.

Mustafa, Aminuddin, and Siti Nurul Aziera Moharani. "Isu dan Permasalahan Keterangan Kanak-kanak di Bawah Undang-Undang di Malaysia: Satu Penilaian." Journal Kanun 1, no. 1 (2012).

Nemie, Puteri. Adopting a No-Fault Compensation System for Medical Injuries in Malaysia. A Myth or Reality? Issues in Medical Law \& Ethics. Kuala Lumpur: Medical Law and Ethics Unit Law Centre, 2003.

Tijdschrift Voor Gezonddheidsrecht/Revue de Droit de La Sante, Belgia, 19981999, n.d.

Othman, Aida. "Introducing Alternative Dispute Resolution in Malaysia: Prospects and Challenges." Malayan Law Journal 2 (2002): 224.

Paul, Agustine. "Evidence-Practice and Procedure." Malayan Law Journal 5 (2003).

Putusan Banding Pengadilan Tinggi Jakarta Pusat No. 393/PID/2016/PT.DKI (2016).

al-Qurțubiy, Abī 'Abdullāh Muhammad bin Aḥmad al-Anșāriy. al-Jāmi' li Aḥkām al-Qur'ān. Qāhirah: Dār al-Sha'bi, n.d.

Rajan, PS. Medical Negligence Litigation: Time for Reform, Issues in Medical Law and Ethics. Kuala Lumpur: Medical law and Ethics Unit, Law Centre, 2003.

Ramalinggam. "Reversal Burden of Proof in Malaysia." 2016.

Sābiq, Sayyid. Fiqh Al-Sunnah. Beirut: Dār al-Fikr, 1977.

San, Tay Pek. "Medical Negligence Litigation Call for a Reconsideration." Malayan Law Journal Sdn. Bhd 3 (1998): Ixxxi.

Soekanto, Soerjono. "Etika Kesehatan-Etika Kedokteran Hukum Medik." Majalah Hukum Varia Peradilan 2, no. 18 (1987). 
Statsky, William. West's Legal Thesaurus/Dictionary. St. Paul: West Publishing Co., 1985.

Stygall, G. "A Different Class of Witnesses: Experts in the Courtroom." Discourse Studies 3, no. 3 (August 1, 2001): 327-49. https://doi.org/10.1177/ 1461445601003003004.

- - - Trial Language: Differential Discourse Processing and Discursive Formations. Amsterdam: John Benjamins Publishing Co., 1994.

Susanti, Rika. "Peranan Dokter Sebagai Saksi Ahli di Persidangan." Jurnal Kesehatan Andalas 2, no. 2 (2013).

Tan, N H S S. "Deconstructing Paternalism-What Serves the Patient Best?" Singapore Med J 43, no. 3 (2002): 148-51. https://pdfs.semanticscholar. org/0adb/3c72da5cb445361d74bceb3b67f98f5cd86d.pdf.

Wehr, Hans. A Dictionary of Modern Written Arabic. London: MacDonald \& Evans Ltd., 1980.

Yaqin, Anwarul. "Legal Research and Writing." Malayan Law Journal Sdn Bhd 1 (2007).

Yeo, Khee Quan. Essentials of Medical Law. Singapore: Sweet \& Maxwell Asia, 2004.

al-Zuhailiy, Wahbah. Fiqh al-Islām wa Adillatuhu. Beirut: Dār al-Fikr, 1989. 
72 || Vol 28, No. 1, April 2018 AL-AHKAM 